\title{
Correction to: Factor Xa Inhibition with Apixaban Does Not Influence Cardiac Remodelling in Rats with Heart Failure After Myocardial Infarction
}

\author{
Salva R. Yurista ${ }^{1} \cdot$ Herman H. W. Silljé ${ }^{1} \cdot$ Kirsten T. Nijholt ${ }^{1} \cdot$ Martin M. Dokter ${ }^{1}$ • Dirk J. van Veldhuisen ${ }^{1}$. \\ Rudolf A. de Boer ${ }^{1}$. B. Daan Westenbrink ${ }^{1}$
}

Published online: 1 July 2020

(C) Springer Science+Business Media, LLC, part of Springer Nature 2020

\section{Correction to: Cardiovascular Drugs and Therapy (6999)} https://doi.org/10.1007/s10557-020-06999-7

Certain paragraph of the article should be written as follows:

MI surgery increased the myocardial expression of atrial natriuretic peptide (ANP) and brain natriuretic peptide (BNP) and increased the relative expression of foetal $(\beta-\mathrm{MHC})$ compared to with that of adult ( $\alpha$-MHC) myosin heavy-chain isoform (i.e. $\beta-\mathrm{MHC} / \alpha-\mathrm{MHC}$ ratio), as markers for foetal gene reprogramming in heart failure (Fig. 2d). The mRNA levels of cardiac fibrosis markers collagen, type I, alpha 1 (COL1A1) and tissue inhibitor of metalloproteinases 1 (TIMP1) were also significantly increased in the hearts of rats following MI, compared with that in the hearts of sham rats (Fig. 2e). Apixaban treatment had no effect on ANP, BNP, $\beta-\mathrm{MHC} / \alpha-\mathrm{MHC}$ ratio, COL1A1 or TIMP1 mRNA levels (Fig. 2d, e).

The original version of this article was revised.

Publisher's Note Springer Nature remains neutral with regard to jurisdictional claims in published maps and institutional affiliations.

The online version of the original article can be found at https://oi.org/ 10.1007/s10557-020-06999-7

B. Daan Westenbrink b.d.westenbrink@umcg.nl

1 Department of Cardiology, University Medical Center Groningen, University of Groningen, PO Box 30.001, Groningen 9700, RB, The Netherlands 